\title{
CHARACTERISATION OF BYZANTINE AND EARY ISLAMIC PRIMARY TANK FURNACE GLASS
}

Dieter Brems $^{\mathrm{a}, \mathrm{b}, *}$, Ian C. Freestone ${ }^{\mathrm{b}}$, Yael Gorin-Rosen ${ }^{\mathrm{c}}$, Rebecca Scott ${ }^{\mathrm{a}}$, Veerle Devulder ${ }^{\mathrm{a}, \mathrm{d}}$, Frank Vanhaecke ${ }^{\mathrm{d}}$ and Patrick Degryse ${ }^{\mathrm{a}, \mathrm{e}, *}$

a. KU Leuven, Department of Earth and Environmental Sciences, Division Geology, Celestijnenlaan 200E, 3001 Leuven, Belgium

b. University College London, Institute of Archaeology, 31-34 Gordon Square, London WC1H OPY, UK

c. Israel Antiquities Authority, POB 586, Jerusalem 91004, Israel

d. Universiteit Gent, Department of Analytical Chemistry, Campus Sterre, Krijgslaan 281 S12, 9000 Ghent, Belgium

e. Leiden University, Faculty of Archaeology, Archaeological Sciences, Einsteinweg 2, 2333

CC Leiden, The Netherlands

* Corresponding author

patrick.degryse@kuleuven.be

Tel.: +32 16326460

Fax: +3216322980

\section{ABSTRACT}

In order to improve the understanding of glass production and provenance, we present trace element and $\mathrm{Sr}, \mathrm{Nd}$ and $\mathrm{B}$ isotope ratio data for 15 samples of raw natron glass from a single tank furnace in Apollonia $\left(6^{\text {th }}-7^{\text {th }}\right.$ century C.E.) and eight glass samples from two tank furnaces in Bet Eli'ezer ( $8^{\text {th }}$ century C.E.) in Israel. This data provides information about the geochemical homogeneity within a single batch of raw glass and about the differences and/or similarities between different tank furnaces on a single site. Four glasses from a secondary workshop at Tell el-Ashmunein, Egypt $\left(8^{\text {th }}-9^{\text {th }}\right.$ century C.E. $)$ are analysed for comparative purposes.

All raw glass samples have uniform trace element patterns and ratios. Because of poor mixing of the glass batch before and during firing, absolute concentrations however can vary significantly within a single tank furnace. The concentrations of trace elements commonly associated with (de)colouring are very low and can be attributed to background concentrations in the sand raw materials. This indicates that there was no obvious recycling of glass cullet at this stage of the production process and that the tank furnace glass is primary glass in the true sense of the word. The isotopic compositions of $\mathrm{Sr}, \mathrm{Nd}$ and $\mathrm{B}$ in the tank furnace glasses are relatively homogeneous. This confirms their potential as provenance indicators. The isotopic composition of $\mathrm{Sr}$ in tank furnace glass from Apollonia and Bet Eli'ezer indicates that the lime was derived from seashell, suggesting the glass was produced from beach sand. Glass from Tell el-Ashmunein contains $\mathrm{Sr}$ with lower ${ }^{87} \mathrm{Sr} /{ }^{86} \mathrm{Sr}$ ratios, pointing to the use of limestone as the source of lime. All primary glasses from Israel analysed have $\mathrm{Nd}$ isotopic compositions typical for an Eastern Mediterranean origin. $\delta^{11} \mathrm{~B}$ indicates that natron used in the tank furnaces in Apollonia and Bet Eli'ezer was most likely imported from Egypt. 


\section{HIGHLIGHTS}

- Trace element and $\mathrm{Sr}, \mathrm{Nd}$ and B isotopic characterisation of primary tank furnace glass

- Provenancing raw materials used in the production of primary glass

- Geochemical homogeneity within a single batch of raw glass

- Differences and similarities between tank furnace glass on a single site

KEYWORDS: NATRON GLASS; TANK FURNACES; TRACE ELEMENTS; SR; ND; B; ISOTOPE RATIOS

\section{INTRODUCTION AND OBJECTIVES}

Ancient natron glass is a complex material. It was produced by melting a calcareous silica sand together with a soda-rich flux. The currently preferred model for natron glass production in the Hellenistic to early Islamic period is one of a division of production (Nenna et al., 1997, 2000, 2005; Gorin-Rosen, 2000; Freestone et al., 2000, 2002a, b; Picon and Vichy, 2003; Tal et al., 2004; Freestone, 2006; Degryse, 2014). The glass was first produced from sand and natron raw materials in tank furnaces on primary production sites. Examples of such installations have been discovered in Egypt and Syro-Palestine. In the Wadi Natrun region, Egypt, three primary production sites were dated between the $2^{\text {nd }}$ century B.C.E. and the $3^{\text {rd }}$ century C.E. (Nenna et al., 2005; Nenna, 2015). Near Alexandria, two other primary workshops were discovered dating from the Imperial period to the $8^{\text {th }}$ century C.E. (Nenna et al., 2000). An early Roman ( $1^{\text {st }}$ century B.C.E. $-1^{\text {st }}$ century C.E.) production site was found in Beirut, Lebanon (Kouwatli et al., 2008; Henderson, 2013). By far most of the remnants of primary natron glass production have been discovered in Israel. 17 tank furnaces with a (minimum) capacity of 8 to 10 tonnes of glass each were found at Bet Eli'ezer (Gorin-Rosen, $1995,2000)$. A number of similar installations for glass production from the $6^{\text {th }}$ to $7^{\text {th }}$ century C.E. were found in Apollonia (Tal et al., 2004; Freestone et al., 2008) and an in situ failed glass slab was discovered in Bet She'arim (early $9^{\text {th }}$ century; Brill, 1967; Freestone and Gorin-Rosen, 1999). Evidence of primary production is also found on other archaeological sites in Israel.

The large tank furnaces were capable of producing several tonnes of raw glass in a single firing, which probably lasted in the order of two weeks or more (Gorin-Rosen, 2000). Numerical simulations using a 3D computation fluid dynamics model based on the primary tank furnaces at Bet Eli'ezer predict that the average temperature of the glass reached $1200^{\circ} \mathrm{C}$ with a minimum of $1080^{\circ} \mathrm{C}$ at the bottom of the tank (Van Beeumen, 2011; Van Beeumen et al., 2011). Sand and natron raw materials were probably introduced into the furnace in several smaller batches during the firing process (Freestone et al., 2000). In this way, the added batch would float on top of an already molten layer of glass, heating the raw materials from below while hot gasses heat them from above. When all raw materials were melted, the glass was allowed to cool down in the tank itself. Once solidified, the furnace was dismantled and the glass slab broken into chunks which were traded widely to be shaped into vessels in secondary workshops (Nicholson et al., 1997; Rehren and Putsch, 1997; Foy et al., 2000; Freestone et al., 2000; Nenna et al., 2000). Additives such as colourants and/or opacifiers were added to the glass at this stage (Freestone et al., 2002a; Picon and Vichy, 2003).

The very nature of glass, with its amorphous structure, limits the number of techniques that can be used to relate it back to its original production site. The provenance determination of natron glass relies solely on consistent and measurable differences in bulk geochemical characteristics between glass from different primary sources. In the literature, several major 
compositional groups have been identified (e.g., Bimson and Freestone, 1985; Gratuze and Barrandon, 1990; Freestone et al., 2000, 2002a; Foy et al., 2003). Each is restricted in chronological and geographical distribution and some can be related to the identified primary glass production centres in Egypt and the Levant. For others, the actual production sites are still unknown.

Unfortunately, the compositional ranges of different glass groups are not clearly defined. There are subtle differences in composition within groups and there can be considerable overlap in geochemical signatures of different possible sources. Small differences in the relative proportion of (alumino-) silicates and carbonates in a sand deposit can result in local variations in, e.g., $\mathrm{CaO}$ and $\mathrm{Al}_{2} \mathrm{O}_{3}$ concentrations of a few weight percent (Brems et al., 2016). The local concentration of heavy minerals due to changing hydraulic conditions, would result in strong peaks in the concentrations of certain trace elements (Brems and Degryse, 2014). It is not unreasonable to assume that the mixing of a great volume of sand with natron in a tank furnace would eliminate some of these heterogeneities. However, incomplete mixing of the sand and natron before firing would result in significant local variations in, e.g., $\mathrm{Na}_{2} \mathrm{O}$ vs. $\mathrm{SiO}_{2}$ and $\mathrm{CaO}$ contents. Convective currents in the volume of molten glass during firing, could result in at least some degree of homogenisation in the geochemical characteristics of the glass (Van Beeumen, 2011; Van Beeumen et al., 2011), but the extent of this is not well known. Freestone et al. (2000) and Tal et al. (2004) already noted significant variation in major element concentrations in glass samples from a single tank furnace.

During the last decades, the emphasis in studies of ancient glass has shifted more and more towards trace elements and isotope ratios (Wedepohl and Baumann, 2000; Freestone et al., 2000, 2003; Degryse et al., 2006, 2009a; Shortland et al., 2007; Degryse and Schneider, 2008; Degryse and Shortland, 2009; Brems et al., 2013a, b; Brems and Degryse, 2014; Degryse, 2014; Devulder et al., 2014). These are likely to be more indicative of the geological (and geographical) source of the sand raw materials than major elements. However, up till now it is unclear how much variation in these geochemical characteristics can be expected within and between primary glass batches. The aim of this paper is to provide a comprehensive geochemical characterisation of raw natron glass from Byzantine and early Islamic tank furnaces in order to investigate the magnitude of variation in trace elemental and $\mathrm{Sr}, \mathrm{Nd}$ and $\mathrm{B}$ isotopic properties within a single batch of raw natron glass. Also the similarity in geochemical composition between different tank furnaces from a single site is investigated.

\section{MATERIALS}

In this study, we provide a geochemical characterisation of raw glass from primary tank furnaces from two sites in Israel: Apollonia and Bet Eli'ezer. We determined trace element compositions and $\mathrm{Sr}, \mathrm{Nd}$ and $\mathrm{B}$ isotopic signatures for 15 samples of raw glass recovered from a single tank furnace in Apollonia, dated to the $6^{\text {th }}-7^{\text {th }}$ century C.E. (Area $\mathrm{N}$ tank; Tal et al., 2004). Major element compositions of these samples have previously been characterized using EPMA (Tal et al., 2004). Additional major element data and selected trace element data for other samples from the site are given by Freestone et al. $(2000,2008)$ and Phelps et al. (2016). The glasses from the Apollonia furnaces are soda-lime-silica glasses typical of late Byzantine and early Islamic glass from the Levantine coast. They are characterized by $\mathrm{Al}_{2} \mathrm{O}_{3}$ contents of about 3.0-3.5\% and $\mathrm{CaO}$ levels in the range of $7-9 \%$. The $\mathrm{Na}_{2} \mathrm{O}$ content is about $12-15 \%$ and that of $\mathrm{SiO}_{2}$ is typically about 69-73\%. The Apollonia glass has been grouped under the name 'Levantine I' (Freestone et al., 2000; Tal et al., 2004), together with, among others, $4^{\text {th }}$ century glass from Jalame (Brill, 1988) and $6^{\text {th }}-7^{\text {th }}$ century glass from Bet She'an, Dor and Ramla (Freestone et al., 2000, 2003; Tal et al., 2008). Although these assemblages have slightly different compositions, they are all believed to be produced along the Palestinian 
coast using very similar 'Belus-type' sand raw materials (Brill, 1988; Freestone and GorinRosen, 1999; Freestone et al., 2000). All 15 samples came from the same tank furnace. Most of them had a natural blue-green (aqua) colour, but five samples (AP04, AP12, AP13, AP14 and AP15) were olive green. Sample AP10 contained stones visible to the naked eye and shows anomalously high $\mathrm{Al}_{2} \mathrm{O}_{3}$ and $\mathrm{Fe}_{2} \mathrm{O}_{3}$ concentrations, and low $\mathrm{Na}_{2} \mathrm{O}$ and $\mathrm{CaO}$ ones, attributed to contamination by contact with the wall or floor of the furnace (.Tal et al., 2004). This sample was split in two. One part (sample AP10a) was composed of relatively clear, transparent aqua glass with no macroscopic inclusions. The second part (AP10b) was almost completely composed of fritted material, i.e. crystalline grains, mostly of quartz, embedded in a glassy matrix. These two samples were analysed separately for their trace elemental and $\mathrm{Sr}$ and $\mathrm{Nd}$ isotopic signatures.

At Bet Eli'ezer, 17 tank furnaces were found, dating to the $8^{\text {th }}$ century C.E. (Gorin-Rosen, 1995, 2000). Freestone et al. (2000) analysed the major element compositions of glass from four furnaces at Bet Eli'ezer. They showed that there are no consistent compositional differences between furnaces on the same site and that the full spread of compositions can be found within glass from a single furnace. Although there is considerable overlap in composition between glass from Apollonia and Bet Eli'ezer, the Bet Eli'ezer glass tends to be lower in soda (mostly 11-13\%) and lime (6-8\%) and higher in silica (73-77\%). This indicates a slight difference in mineralogical composition of the glassmaking sands used and a decrease in the amount of natron flux that was added to the batch (Freestone et al., 2008). The Bet Eli'ezer glass has been termed 'Levantine II' (Freestone et al., 2000). A total of eight raw glass samples were analysed from two tank furnaces in Bet Eli'ezer: five samples from a first furnace (context L22.B261; Freestone et al., 2000) and three from a second (context L14.B190; Freestone et al., 2000). Major element compositions of these samples are reported by Freestone et al. (2000). Sample BE39 showed some variation in colour on a scale of a few $\mathrm{mm}$ and was subsampled for the trace element and isotopic analyses. Sample BE39a was mostly blue coloured, while BE39b was darker green.

To put the degree of heterogeneity within the tank furnaces into perspective, we included some other glass from a very different context in the analyses. Three vessel glasses (TA01, TA02 and TA03) and a piece of glass waste (TA04) from a secondary glass workshop at Tell el-Ashmunein, Egypt, were also analysed. These glasses were dated to the $8^{\text {th }}-9^{\text {th }}$ century C.E. (Freestone et al., 2003). The major element composition of these glasses was previously determined by Bimson and Freestone (1985). They belong to a glass group called 'Egypt II', characterised by rather high lime and relatively low alumina contents (Bimson and Freestone, 1985; Gratuze and Barrandon, 1990; Freestone et al., 2000).

\section{METHODS}

Small fragments from all glass samples were mounted in transparent epoxy resin blocks and ground and polished down to $1 \mu \mathrm{m}$ to expose uncorroded glass. Trace element data were obtained via Laser Ablation - Inductively Coupled Plasma - Mass Spectrometry (LA-ICPMS) at the Centre for Archaeological and Forensic Analysis, Cranfield University. A comparison of reference trace element concentrations for Corning Museum Ancient Glass Standard A (Brill, 2012; Wagner et al., 2012) and measured values are given in Table 1. For most trace elements determined, the measured values are within $10 \%$ of the published values, however, $\mathrm{B}, \mathrm{Nb}, \mathrm{Sn}$ and $\mathrm{Pb}$ are within $20 \%$ of the published values. The values obtained for As were consistently almost double the value reported by Brill (2012). No adjustments were made for these deviations in the reported data in Table 2. The concentration of elements belonging to the lanthanide series ( $\mathrm{La}$ to $\mathrm{Lu}$ ) is very low in the Corning A standard and to the best of the authors' knowledge no reliable reference values have been published. According to 
our measurements, the concentrations in the Corning A glass are one to two orders of magnitude lower than in the samples reported in Table 2. These data should however be treated with caution.

After separating $\mathrm{Sr}, \mathrm{Nd}$ and $\mathrm{B}$ from the sample solutions using sequential extraction procedures, ${ }^{87} \mathrm{Sr} /{ }^{86} \mathrm{Sr},{ }^{143} \mathrm{Nd} /{ }^{144} \mathrm{Nd}$ and ${ }^{11} \mathrm{~B} /{ }^{10} \mathrm{~B}$ isotope ratios were measured using Multi Collector - Inductively Coupled Plasma - Mass Spectrometry (MC-ICP-MS) at the Department of Analytical Chemistry, Ghent University. Details on the sample preparation and analytical conditions can be found in De Muynck et al. (2009), Ganio et al. (2012a) and Devulder et al. (2013).

\section{RESULTS AND DISCUSSION}

The results of the trace element and $\mathrm{Sr}, \mathrm{Nd}$ and $\mathrm{B}$ isotopic analyses are listed in Table 2. This table also contains major element data as determined by Bimson and Freestone (1985), Freestone et al. (2000) and Tal et al. (2004).

The trace element composition of natron glass is a combination of elements derived from all the raw materials used: the (calcareous) sand, the natron and the lime, and possibly from any colourants that were added to the glass batch. Brems and Degryse (2014) classified all elements of the periodic table according to their most likely source and in particular those exclusively related to the sand source are of interest as possible provenance indicators. The elements that are the most diagnostic to distinguish between different suitable sand raw materials are Ti, Cr, Sr, Zr and Ba (Brems and Degryse, 2014).

Samples AP10a and AP10b from Apollonia contain relatively elevated trace element concentrations ( $\mathrm{Ti}, \mathrm{V}, \mathrm{Cr}, \mathrm{Ni}, \mathrm{Y}, \mathrm{Zr}, \mathrm{Nb}, \mathrm{Hf}$, Th and REE) when compared to the other samples analysed. Freestone et al. (2000) already suggested that these samples were contaminated by contact with the wall or floor of the furnace, based on their higher $\mathrm{Al}_{2} \mathrm{O}_{3}$ and $\mathrm{Fe}_{2} \mathrm{O}_{3}$ contents. The higher concentrations of trace elements observed here can also be attributed to the interaction between the molten glass and the clay bricks of the furnace wall during firing. Since these samples are not representative for the bulk of the tank furnace, they are excluded from the rest of the discussion. However, it is possible that such pieces were not discarded after breaking up the primary glass slab and that they were sold together with the rest of the raw glass. If they were remelted together with pristine raw glass during secondary production, the resulting object would show a slightly anomalous chemical composition with higher trace element concentrations.

To a lesser extent, samples $\mathrm{BE} 39 \mathrm{a}$ and $\mathrm{BE} 39 \mathrm{~b}$ also show slightly higher $\mathrm{Al}_{2} \mathrm{O}_{3}, \mathrm{Fe}_{2} \mathrm{O}_{3}$ and trace element concentrations than other samples from the first tank furnace at Bet Eli'ezer. This might suggest that here also there was some minor interaction between the glass and the furnace wall. However, a local increase in the concentration of clayey material in the sand raw material and the glass batch can also explain these observations.

\subsection{Sand-related trace elements}

The alkali metals $\mathrm{Rb}$ and $\mathrm{Cs}$ have similar geochemical properties to $\mathrm{K}$ and in sands they are mostly present in feldspar. As a result there is a good correlation between $\mathrm{Rb}, \mathrm{Cs}, \mathrm{K}_{2} \mathrm{O}$ and $\mathrm{Al}_{2} \mathrm{O}_{3}$ in the glasses analysed. In the samples from the primary tank furnaces, the concentration of $\mathrm{Rb}$ ranges from 6.3 to $13.4 \mathrm{ppm}$ and that of $\mathrm{Cs}$ from 0.08 to $0.20 \mathrm{ppm}$. The Egyptian samples have systematically lower concentrations ( $\mathrm{Rb}$ between 2.2 and $4.0 \mathrm{ppm}$, Cs between 0.04 and $0.06 \mathrm{ppm}$ ), which is in accordance with their low $\mathrm{K}_{2} \mathrm{O}$ and $\mathrm{Al}_{2} \mathrm{O}_{3}$ contents.Likewise, the alkaline earth metals $\mathrm{Sr}$ and $\mathrm{Ba}$ can substitute for $\mathrm{Ca}$ in Ca-rich minerals. The main source of $\mathrm{Ca}$ in natron glass was calcium carbonate in the form of 
limestone or shell fragments. There is a major difference in the concentration of Sr between the samples from Israel and Egypt. Glass from Bet Eli'ezer and Apollonia shows a relatively wide range of $\mathrm{Sr}$ concentrations between 328 and $615 \mathrm{ppm}$. Glass from Tel el-Ashmunein has lower Sr contents between 146 and $182 \mathrm{ppm}$. These data are consistent with previously reported values from the same sites (Freestone et al., 2003; Phelps et al., 2016). The concentration of $\mathrm{Sr}$ in natron glass is a good proxy for the nature of the lime source used (Wedepohl and Baumann, 2000; Freestone et al., 2003; Brems et al., 2013a). The relatively high concentration of $\mathrm{Sr}$ in the Levantine glass indicates that the lime was mostly derived from seashells. The lower Sr concentration in the Egyptian glass is attributed to the use of limestone as the source of lime in the glass batch. The Ba concentrations in the glass from Apollonia and Bet Eli'ezer range between 207 and $281 \mathrm{ppm}$. Tel el-Ashmunein glass has lower Ba concentrations between 130 and $174 \mathrm{ppm}$.

Transition metals of groups 3, 4, 5 and 6 of the periodic table ( $\mathrm{Sc}, \mathrm{Ti}, \mathrm{V}, \mathrm{Cr}, \mathrm{Y}, \mathrm{Zr}, \mathrm{Nb}, \mathrm{Mo}$, $\mathrm{La}, \mathrm{Hf}, \mathrm{Ta}, \mathrm{W}$ and $\mathrm{Th}$ ) and elements of the lanthanide series mostly enter the glass with the source of silica (Brems and Degryse, 2014). These elements are associated with the heavy mineral fraction of the sand raw material, which can be indicative of the geological setting. The concentrations of these elements in natron, lime and colouring agents are much lower.

The elements $\mathrm{Zr}$ and $\mathrm{Hf}$ are almost completely derived from the heavy mineral zircon, which is a common accessory mineral in sands. Therefore, their concentrations are always very strongly correlated. The $\mathrm{Zr}$ and $\mathrm{Hf}$ contents in the glasses from the primary tank furnaces range from 35 to $69 \mathrm{ppm}$ and from 0.9 to $1.8 \mathrm{ppm}$, respectively, and $\mathrm{Zr}$ and Hf are indeed very strongly correlated (correlation coefficient $r=0.97$ ). The glass samples from the secondary workshop at Tell el-Ashmunein show higher concentrations with Zr between 101 and 221 ppm and $\mathrm{Hf}$ between 2.4 and $5.3 \mathrm{ppm}$.

$\mathrm{TiO}_{2}$ is mostly present in heavy minerals such as ilmenite, rutile and anatase. Since different heavy minerals behave in a similar way in sedimentary environments, $\mathrm{TiO}_{2}$ and $\mathrm{Zr}$ concentrations are very often correlated in sediments. Therefore we can expect the same in glass produced with natural sands. $\mathrm{TiO}_{2}$ concentrations range from 0.07 to $0.18 \%$ in the glasses from the primary tank furnaces and from 0.18 to $0.29 \%$ in the samples from Tell elAshmunein. The $\mathrm{TiO}_{2}$ versus $\mathrm{Zr}$ biplot indeed shows the expected correlation (Fig. 1). The Egyptian samples can be distinguished from the Levantine glasses based on their higher $\mathrm{TiO}_{2}$ and $\mathrm{Zr}$ contents. There is however an important difference in the slope of the correlation curves that can be drawn through the data points of the primary tank furnaces and those of the Tell el-Ashmunein samples. The Egypt II glasses appear to be relatively enriched in $\mathrm{Zr}$, which results in higher $\mathrm{Zr} / \mathrm{TiO}_{2}$ ratios. This shows that the two glass groups are produced using sand raw materials with a fundamentally different geological origin and not from sand with the same basic geological origin but with a different degree of maturity (more reworking with the elimination of heavy minerals). 


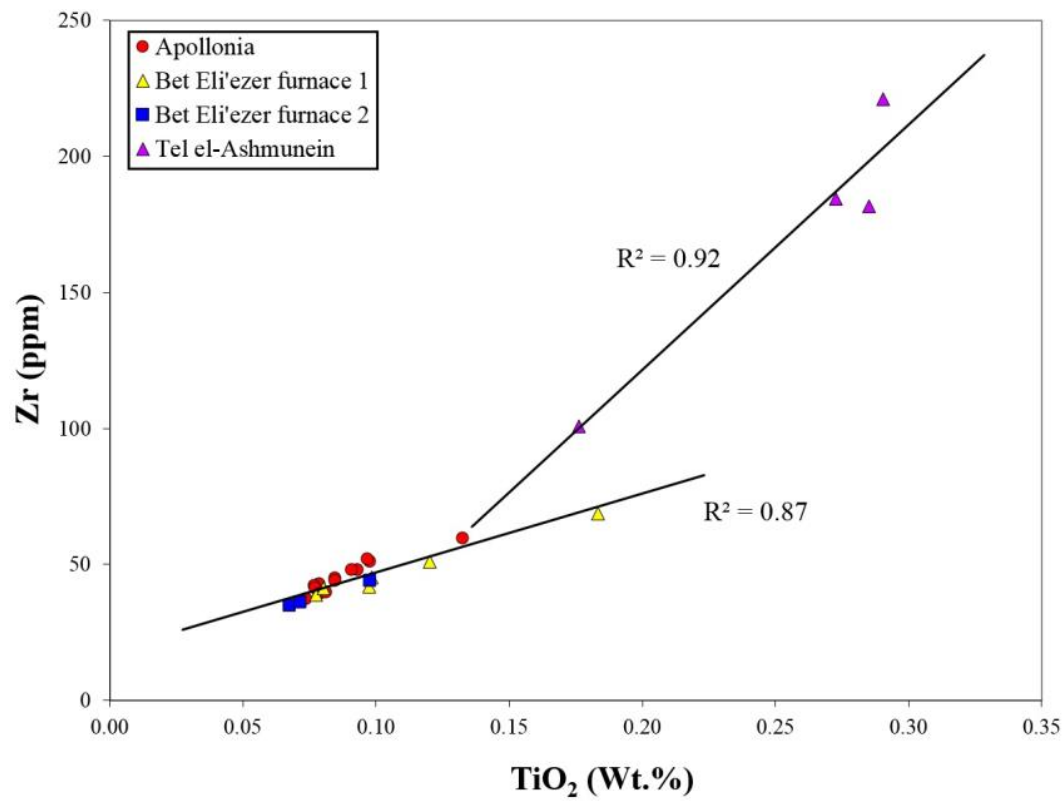

Figure 1: Co-variation of $\mathrm{TiO}_{2}$ with $\mathrm{Zr}$ in the glasses analysed. Separate trend lines are drawn through the samples from Tell el-Ashmunein and those from the tank furnaces.

Cr concentrations in the tank furnace glasses vary between 11 and $23 \mathrm{ppm}$. In the glass from Egypt, Cr ranges from 16 to $27 \mathrm{ppm}$. V, Nb and Th generally follow the same pattern (Table 2): (1) their absolute concentrations can vary within the tank furnaces, (2) their concentration is generally somewhat higher in the glass from Tell el-Ashmunein, and (3) they are all moderately to strongly correlated. This indicates that these elements all entered the glass with the heavy mineral fraction of the sand raw materials and that the 'Levantine I' and 'Levantine II' glasses were produced with sands which contained less heavy minerals than the 'Egypt II' glass.

When sample TA02 is excluded from the data set (because of its high MnO content, see below), we find strong positive correlations between $\mathrm{MnO}, \mathrm{Y}$ and the REEs. This suggests that they enter the glass together. The Levantine and Egyptian glasses have similar concentrations of these elements. However, the samples from Tell el-Ashmunein appear to have slightly depleted $\mathrm{Eu}$ concentrations as can be seen in the chondrite-normalised REE patterns (Fig. 2). This can be related to their relatively low $\mathrm{Al}_{2} \mathrm{O}_{3}$ concentrations. Unlike the other REEs, Eu can occur in a divalent state and can be incorporated in plagioclase feldspar. When a sand deposit is relatively depleted in plagioclase, this can cause a negative Eu anomaly. This anomaly in the Egyptian glasses is however small. All the REE patterns are rather similar. Previous studies have already shown that REE patterns are of little use as provenance indicators for ancient natron glass (Degryse and Shortland, 2009; Walton et al., 2009; Brems and Degryse, 2014).

Fig. 3 shows the concentrations of a selection of sand-related trace elements normalised to the average continental Earth's crust (Wedepohl, 1995). All glasses from Bet Eli'ezer and Apollonia have homogeneous trace element patterns and ratios, which are very similar to the average trace element pattern for Belus River sands (Fig. 3; Brems and Degryse, 2014). This indicates geochemical homogeneity of the sand sources along the Levantine coast. These very similar trace element patterns are not surprising since most of the sand along these coasts is ultimately derived from the River Nile. The heavy mineral assemblage in the sand deposits will therefore be very similar. The distribution of these minerals in a sand deposit can however vary locally due to varying hydraulic conditions during sediment deposition (Brems et al., 2016). As a result, the absolute concentrations of these elements can vary substantially. 
Since primary glass batches seem to be poorly mixed (as evidenced by the variations in major element concentrations; Freestone et al., 2000), these variations will be transferred to the final glass slab. However, different heavy minerals will react to varying hydraulic conditions in a similar fashion. Therefore, although absolute concentrations may vary, trace element ratios will mostly be left unchanged.
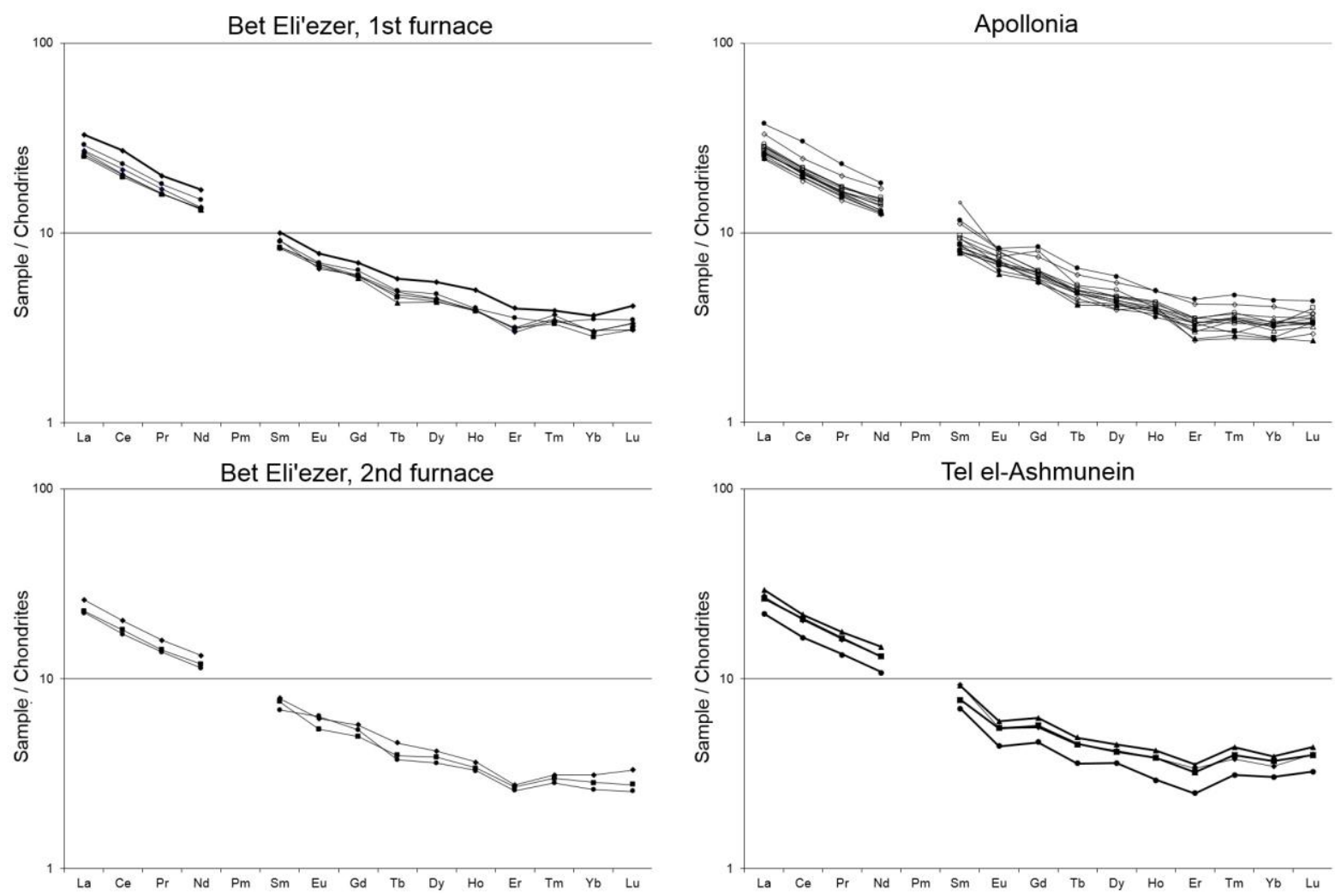

Figure 2: Chondrite-normalised rare earth element patterns of the glasses analysed. (Chondrite values from Sun and McDonough (1989)).
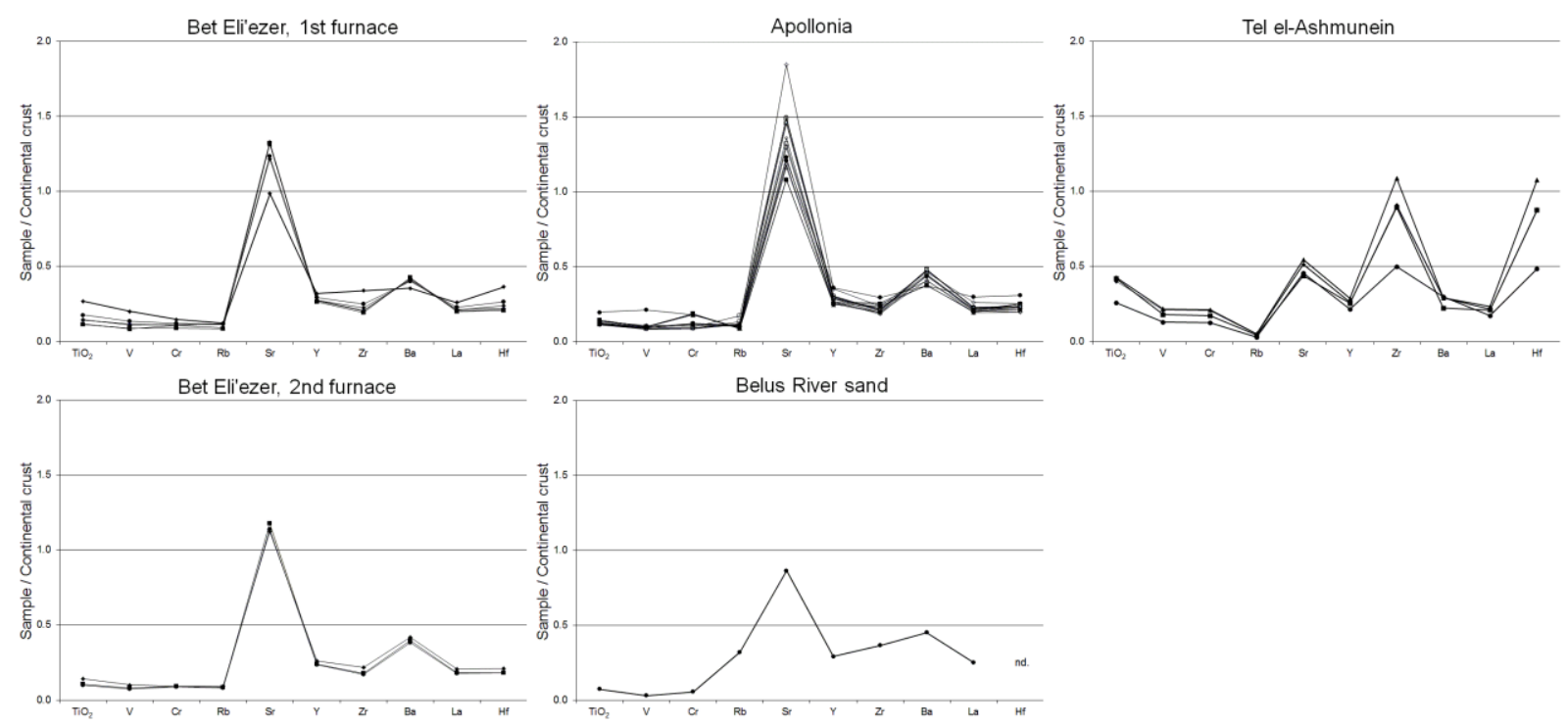

Figure 3: Trace element concentrations normalised to the mean abundances in the Earth's continental crust (Wedepohl, 1995). Every line represents a sample. The trace element pattern of Belus river sand is given for comparison (Brems and Degryse, 2014). 


\subsection{Natron-related trace elements}

The natron flux is the main source of $\mathrm{Na}, \mathrm{S}, \mathrm{F}, \mathrm{Cl}, \mathrm{Br}$ and $\mathrm{I}$ in primary natron glass (Brems and Degryse, 2014). It also introduces most of the $\mathrm{P}, \mathrm{B}$ and $\mathrm{U} . \mathrm{Na}_{2} \mathrm{O}, \mathrm{Cl}$ and $\mathrm{SO}_{3}$ contents were previously determined by Bimson and Freestone (1985), Freestone et al. (2000) and Tal et al. (2004). Although there is overlap in the compositional ranges, the concentrations of $\mathrm{Na}_{2} \mathrm{O}$ and $\mathrm{Cl}$ are generally higher in the Tell el-Ashmunein glass (between 14.7 and $15.3 \%$ $\mathrm{Na}_{2} \mathrm{O}$ and between 1.0 and $1.2 \% \mathrm{Cl}$ ) than in the tank furnace glass (between 10.8 and $16.1 \%$ $\mathrm{Na}_{2} \mathrm{O}$ and between 0.5 and $1.1 \% \mathrm{Cl}$ ). This indicates that the Egypt II glass was produced with a higher proportion of natron in the glass batch. The concentration of $\mathrm{P}_{2} \mathrm{O}_{5}$ is low $(0.03-$ $0.05 \%$ ) in the glasses from the tank furnaces, which is characteristic for glass produced with natron as a flux. Plant ash glass generally contains more $\mathrm{P}_{2} \mathrm{O}_{5}$. One sample from Tell elAshmunein has a slightly higher $\mathrm{P}_{2} \mathrm{O}_{5}$ concentration of $0.16 \%$. This might be the result of accidental incorporation of some ash from the furnace fuel. However, no elevation in the concentration of $\mathrm{K}_{2} \mathrm{O}$ or $\mathrm{MgO}$ is observed. An alternative explanation for the slightly elevated $\mathrm{P}_{2} \mathrm{O}_{5}$ concentration might be the incorporation of some bone (hydroxylapatite) or bone ash in the glass batch.

$\mathrm{U}$ concentrations range from 0.6 to $1.9 \mathrm{ppm}$ in the primary tank furnaces and from 0.9 to 1.5 $\mathrm{ppm}$ in the Tell el-Ashmunein glass. The concentration of $\mathrm{B}$ in the glasses analysed is discussed below together with the B isotope ratios.

\section{3. (De)colourant-related trace elements}

There is no evidence that (de)colouring agents were added to the primary glass batches at Apollonia or Bet Eli'ezer. The concentration of trace elements commonly associated with (de)colouring, such as $\mathrm{Mn}, \mathrm{Sb}, \mathrm{Co}, \mathrm{Ni}, \mathrm{Cu}, \mathrm{Zn}, \mathrm{As}, \mathrm{Ag}, \mathrm{Sn}$ and $\mathrm{Pb}$, are all very low and can be attributed to background concentrations in the sand raw materials (Brems and Degryse, 2014). The concentration of $\mathrm{MnO}$ is $\leq 0.02 \%$. Sb concentrations range from 0.1 to $1.4 \mathrm{ppm}$. The concentrations of the other transition metals are moderately to strongly correlated with sandrelated trace elements like $\mathrm{TiO}_{2}, \mathrm{~V}, \mathrm{Zr}$ and $\mathrm{Cr}$. This indicates that they are indeed coming in with the heavy mineral fraction of the sand raw material. Although the inclusion of some cullet cannot be excluded completely, it is unlikely that strongly coloured fragments were recycled during the primary production process. Therefore the trace element composition of the raw glass presented here is not contaminated by the accidental addition of colouring agents and are true background levels of trace elements in natron glass. This data can therefore be used as comparison for other natron glass studies to investigate whether or not the composition of the analysed glasses has been affected by recycling of cullet.

One fragment of a glass vessel from Tell el-Ashmunein (TA02) has a higher $\mathrm{MnO}$ concentration of $0.67 \%$. This $\mathrm{MnO}$ was deliberately added to the glass to make it colourless (Bimson and Freestone, 1985). Sample TA02 also has slightly higher concentrations of Zn and $\mathrm{Sb}$. In the other samples from Tell el-Ashmunein, the concentrations of (de)colourantrelated trace elements are comparable to those in the primary glasses. This suggests that there were no colouring agents added to the glass and that they are not influenced by recycling of cullet.

\section{4. ${ }^{87} \mathrm{Sr} /{ }^{\beta 6} \mathrm{Sr}$ isotope ratio}

The $\mathrm{Sr}$ isotopic signatures of the glasses analysed from the primary tank furnaces are very homogenous. ${ }^{87} \mathrm{Sr} /{ }^{86} \mathrm{Sr}$ ratios vary between 0.70902 and 0.70919 (Fig. 4). These signatures lie 
very close to the present day seawater value $\left({ }^{87} \mathrm{Sr} /{ }^{86} \mathrm{Sr}=0.709165 \pm 0.000020\right.$; Stille and Shields, 1997; Banner, 2004). This indicates that the main source of lime in these glasses was Holocene seashell (Wedepohl and Baumann, 2000; Freestone et al., 2003, 2009; Brems et al., 2013a). This shell material could have been deliberately added to the glass batch, but it is more likely that it was naturally included in the coastal sands used as a source of silica. Sample AP10b has a slightly higher ${ }^{87} \mathrm{Sr} /{ }^{86} \mathrm{Sr}$ signature of 0.70938 . This can be attributed to contamination from the furnace wall or floor, as is already evident from the elevated concentrations of $\mathrm{Al}_{2} \mathrm{O}_{3}$ and $\mathrm{Fe}_{2} \mathrm{O}_{3}$ (Freestone et al., 2000) and trace elements. This alteration of the strontium isotopic signature due to contamination by the furnace building material has not been reported before and should be kept in mind when interpreting strontium isotope ratios in ancient glass.

Freestone et al. (2003) determined the isotopic composition of $\mathrm{Sr}$ in three glass samples from another tank furnace from Bet Eli'ezer and their results are indistinguishable from the data presented here. This shows that different tank furnaces from Bet Eli'ezer and Apollonia cannot be distinguished from each other based on their Sr isotopic signature.

The Tell el-Ashmunein glass samples have much lower ${ }^{87} \mathrm{Sr} /{ }^{86} \mathrm{Sr}$ isotopic signatures between 0.70794 and 0.70805 . The isotopic composition of $\mathrm{Sr}$ in three of these samples (TA02, TA03 and TA04) was previously determined via TIMS by Freestone et al. (2003). The results presented in this study are within analytical error of the previously published data. These lower $\mathrm{Sr}$ isotopic signatures in the glass from Egypt indicates that limestone was used as the source of lime (Wedepohl and Baumann, 2000; Freestone et al., 2003, 2009).

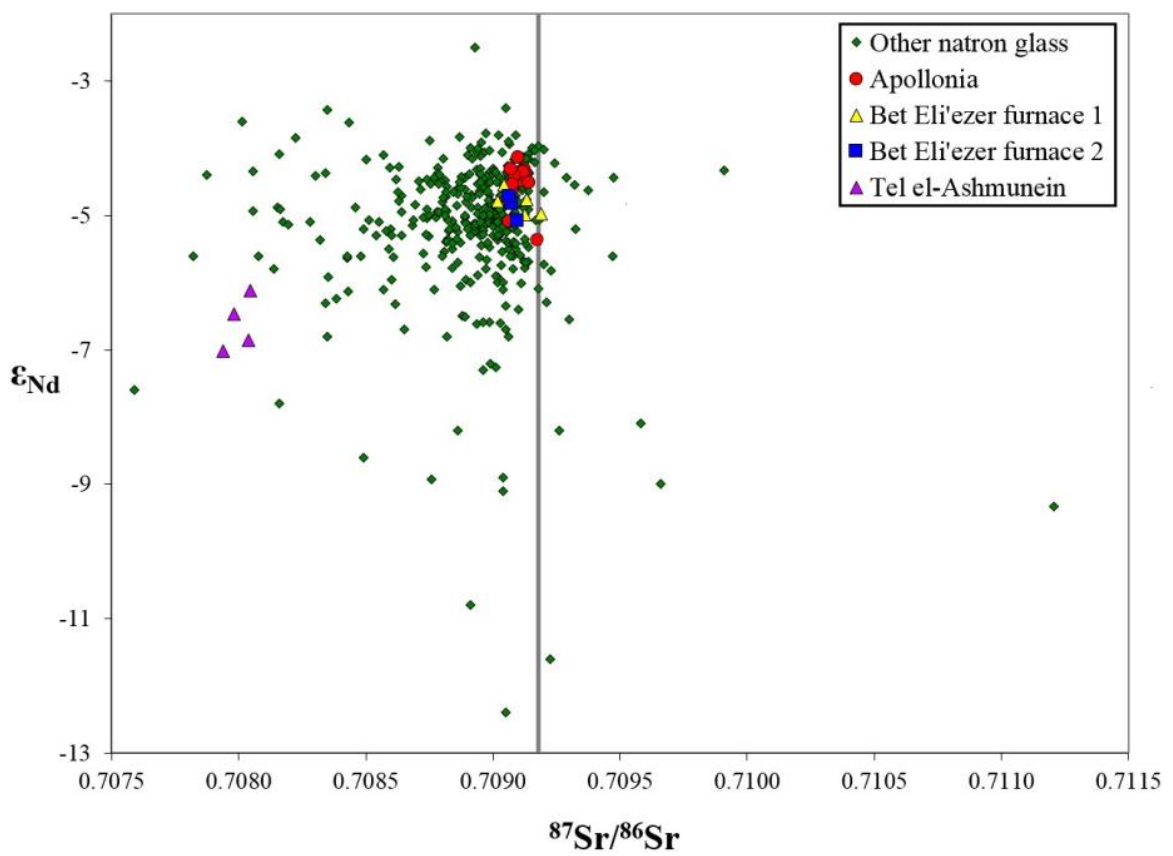

Figure 4: Sr-Nd isotopic composition of the glass analysed in this study and other natron glass (432 analyses from glass dating between the $1^{\text {st }}$ cent. B.C.E. and the $9^{\text {th }}$ cent. C.E. compiled from Degryse et al. $(2006$, 2008, 2009b), Degryse and Schneider (2008), Ganio et al. (2012b, 2012c)) and Degryse (2014)). The ${ }^{87} \mathrm{Sr} /{ }^{86} \mathrm{Sr}$ ratio of present-day seawater is indicated with the grey line.

\section{5. ${ }^{143} \mathrm{Nd} /{ }^{144} \mathrm{Nd}$ isotope ratio $\left(\varepsilon_{N d}\right)$}

The isotopic composition of $\mathrm{Nd}$ in the glass from the tank furnaces ranges between -5.1 and $4.5 \varepsilon_{\mathrm{Nd}}\left(\right.$ for ${ }^{143} \mathrm{Nd} /{ }^{144} \mathrm{Nd}$ ) for glass from Bet Eli'ezer and between -5.4 and -4.1 for raw glass fragments from a single tank furnace in Apollonia (Fig. 4). The ranges of the three different furnaces strongly overlap so they cannot be distinguished from each other. This indicates the 
use of sand raw materials with the same geological origin. The results obtained here are slightly higher than other $\mathrm{Nd}$ isotope ratio data from Israeli tank furnaces ( $\varepsilon_{\mathrm{Nd}}$ values between -6.0 and -5.6 for three samples from another furnace at Bet Eli'ezer and -5.1 for one sample from Apollonia; Freestone et al., 2018). This difference can be attributed to the measuring technique used. In this study, isotope ratios were measured using multi collector ICP-MS, while the data of Freestone et al. (2018) were obtained via TIMS.

Glass from the secondary workshop at Tell el-Ashmunein has $\varepsilon_{\mathrm{Nd}}$ values between -7.0 and 6.1. These are lower than those of the Levantine glasses, which confirms the difference in primary origin of the raw materials used for the production of these glasses. The similarity of the range of $\varepsilon_{\mathrm{Nd}}$ values measured in different furnaces from the same site, and the difference in $\varepsilon_{\mathrm{Nd}}$ values between glasses from different origins are very encouraging for the applicability of $\mathrm{Nd}$ isotopic analysis for provenancing glass.

The results of the Sr-Nd isotopic analyses are compared to the corresponding characteristics of other natron glasses in Fig. 4. These data represent 432 primary and mainly secondary glass fragments from a wide range of archaeological sites in both the eastern and western Mediterranean, dating between the $1^{\text {st }}$ century B.C.E. and the $9^{\text {th }}$ century C.E. (Degryse et al., 2006, 2008, 2009b; Degryse and Schneider, 2008; Ganio et al., 2012b, 2012c; Degryse, 2014). The bulk of the dataset has $\varepsilon_{N d}$ values between -6 and -4 , similar to those found in primary tank furnace glass from Israel. This indicates that the vast majority of natron glass in the $1^{\text {st }}$ millennium C.E. had its primary origin in the eastern Mediterranean. An $\varepsilon_{\mathrm{Nd}}$ value of -7 has been suggested to mark the separation between the eastern and the western Mediterranean (Degryse and Schneider, 2008). Glasses with lower $\varepsilon_{\mathrm{Nd}}$ values may have been produced from their raw materials in the West.

When looking at Fig. 4 , it must be noted that the range of $\varepsilon_{\mathrm{Nd}}$ values measured in a single tank furnace is relatively wide in comparison to the full range of $\mathrm{Nd}$ isotopic signatures reported for secondary glass in literature. This again shows that although the method is very useful to distinguish between wider production regions, i.e. east vs. west, it is not possible to pinpoint a single production site within an area based on $\mathrm{Nd}$ isotope ratios alone.

\section{6. $\mathrm{B}$ concentration and ${ }^{11} \mathrm{~B} /{ }^{10} \mathrm{~B}$ isotope ratio $\left(\delta^{11} \mathrm{~B}\right)$}

The concentration of B in the raw glass from Bet Eli'ezer and Apollonia ranges from 37 to 60 ppm. The isotopic composition of B in these glasses is relatively homogeneous and varies between +22.7 and $+29.9 \% \delta^{11} \mathrm{~B}$. The Egyptian glasses from Tell el-Ashmunein have B concentrations between 73 and $95 \mathrm{ppm}$. Their B isotopic signatures range from +20.4 to $+25.2 \% \delta^{11} \mathrm{~B}$.

In Fig. 5, the B concentration and B isotopic composition in the glasses analysed is compared to those in $4^{\text {th }}$ century B.C.E. to $7^{\text {th }}$ century C.E. vessel glass from Sagalassos (Turkey), Kelemantia (Slovakia), Oudenburg (Belgium) and Grandcourt Farm (UK) (Devulder et al., 2014). Additional comparative data for potential natron and sand raw materials is shown as well (Devulder and Degryse, 2014; Devulder et al., 2014).

A first interesting observation is the difference in B concentration between the raw tank furnace glass analysed in this study and the secondary (vessel) glass from Devulder et al. (2014), which has significantly higher B contents (i.e. between 100 and 300 ppm). This, however, does not necessarily mean that a different flux source was used in their production. On the contrary, the secondary vessel glasses also have higher $\mathrm{Na}_{2} \mathrm{O}$ concentrations and we see a positive correlation between $\mathrm{B}$ and $\mathrm{Na}_{2} \mathrm{O}$. Given the fact that the glass vessels analysed by Devulder et al. (2014) are mostly older, and the B isotopic compositions are fairly similar (Fig. 5), it seems that the vessel glasses were produced with the same type of natron flux as the younger tank furnace glass, but according to a different recipe (i.e. higher natron to sand 
ratio). This is in good agreement of the previously reported trend of decreasing $\mathrm{Na}_{2} \mathrm{O}$ contents in natron glass due to an increasing shortage of natron available for glass production in the second half of the first millennium C.E. (e.g. Freestone et al., 2000; Shortland et al., 2006).

The difference in B concentration between the tank furnace glasses and the glass from Tell elAshmunein is most likely related to a difference in recipe as well. As discussed previously, the Tel el-Ashmunein glass also has higher $\mathrm{Na}_{2} \mathrm{O}$ and $\mathrm{Cl}$ concentrations, indicating the use of more natron in the glass batch. The fact that the Tell el-Ashmunein glass is younger than the tank furnaces in Apollonia and Bet Eli'ezer, might suggest that the primary production site of the Egypt II glass was located closer to the source of natron and was therefore less affected by the declining availability of natron in the Near East.

Also intriguing is that the concentration of $\mathrm{B}$ in the tank furnace glasses and the secondary glasses from literature is higher than in most of the present-day flux material (Fig. 5). This might indicate that the amount of $\mathrm{B}$ that is incorporated in the natron deposits has changed over time or that, as suggested by Shortland et al. (2011) and Devulder et al. (2014), the salts were further processed before using them to produce glass. This process could potentially cause an enrichment of B in the end product. It might also be the result of the separation of an immiscible sodium chloride rich scum or gall during the glassmaking process (e.g. Tanimoto and Rehren, 2008), where, as a glass-former, boron would be expected to be strongly partitioned into the glass melt. This is however highly speculative, since the effect of these manipulations on the B concentration and the B isotopic signature in the flux in unknown.

The $\delta^{11} \mathrm{~B}$ values of the primary glasses reported in this study lie close to those of natron from Egypt, Libya and Tunisia (Fig. 5; Devulder et al., 2014). This suggests that the tank furnaces in Israel imported natron flux from one (or more) of these North-African sources. Lake Pikrolimni in Greece can be excluded as possible natron source for primary glass production in Apollonia and Bet Eli'ezer given its much lower $\delta^{11} \mathrm{~B}$ signature (Fig. 5).

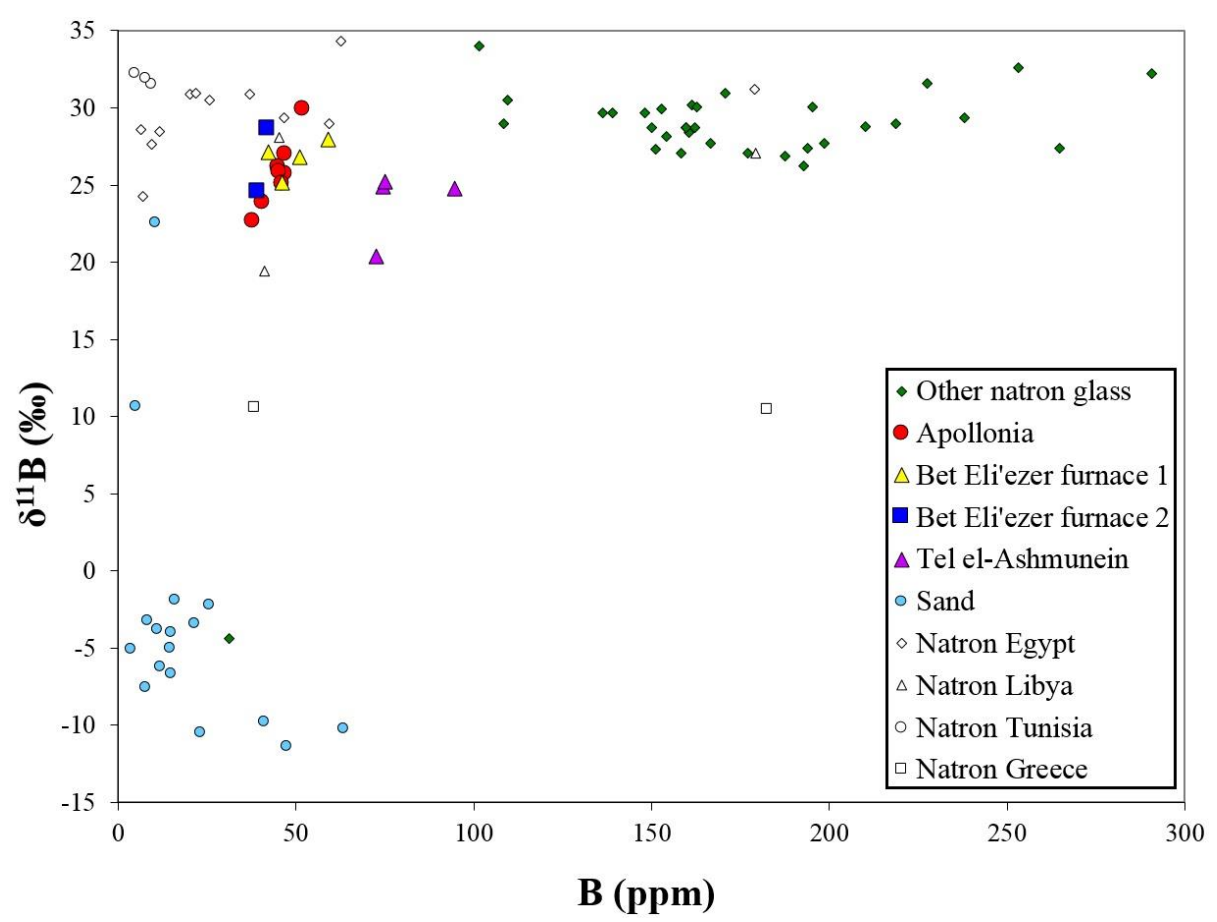

Figure 5: B concentration and B isotopic composition of the glass analysed in this study and other natron glass (33 analyses from glass dating between the $4^{\text {th }}$ cent. B.C.E. and the $7^{\text {th }}$ cent. C.E. from Devulder et al. (2014)), natron from various sources and sand deposits (Devulder and Degryse, 2014; Devulder et al., 2014). 


\section{CONCLUSIONS}

Raw glass from different tank furnaces on a single site have very similar ranges of major, minor and trace element compositions and $\mathrm{Sr}, \mathrm{Nd}$, and $\mathrm{B}$ isotopic signatures. The glass from these tank furnaces cannot be distinguished from each other based on these geochemical characteristics. The isotopic composition of $\mathrm{Sr}$ and $\mathrm{Nd}$ in raw glass fragments from Bet Eli'ezer and Apollonia is relatively homogeneous. This confirms the applicability of this method for provenancing glass on a larger scale. Caution is however warranted since it appears that the isotopic composition of $\mathrm{Sr}$ can be altered by contamination from the furnace walls. The isotopic composition of B in raw glass from Bet Eli'ezer and Apollonia is also relatively homogeneous. Evaporitic lakes in Egypt are the most likely source for the natron flux used for the production of the glass, although other North-African sources cannot be excluded.

Trace element patterns of raw glass from Bet Eli'ezer and Apollonia are very similar to that of Belus River sand. Although compositional ranges are very similar between different tank furnaces, absolute concentrations of major and trace elements within a single tank furnace can vary significantly in comparison to today's analytical precision. This indicates that the raw materials were poorly mixed before firing and that convective currents within the molten glass were insufficient to homogenise the batch.

\section{ACKNOWLEDGEMENTS}

We are grateful to Rita Giannini for assistance in operating the LA-ICP-MS set-up and Kris Latruwe for the help with the MC-ICP-MS analyses. Oren Tal, Rutheve Tal, Jeffrey Spencer and the late Don Bailey kindly provided the samples from Apollonia and Tell el-Ashmunein. The research is financially supported by the ERC Starting Grant ARCHGLASS Grant agreement no. 240750 and the FWO project no. 6.0864.09. Dieter Brems benefitted from a postdoctoral fellowship of the Research Foundation - Flanders (FWO-Vlaanderen).

\section{REFERENCES}

Banner, J.L., 2004. Radiogenic isotopes: systematics and applications to earth surface processes and chemical stratigraphy. Earth Science Reviews 65, 141-194.

Bimson, M., Freestone, I.C. 1985, The discovery of an Islamic glass making site in Middle Egypt. Annales du 10e Congrès de l'Association Internationale pour l'Histoire du Verre, Madrid Segovia, 237243.

Brems, D., Ganio, M., Latruwe, K., Balcaen, L., Carremans, M., Gimeno, D., Silvestri, A., Vanhaecke, F., Muchez, P., Degryse, P., 2013a. "Isotopes on the beach Part 1 - Strontium isotope ratios as a provenance indicator for lime raw materials used in Roman glassmaking." Archaeometry 55, 214-234.

Brems, D., Ganio, M., Latruwe, K., Balcaen, L., Carremans, M., Gimeno, D., Silvestri, A., Vanhaecke, F., Muchez, P., Degryse, P., 2013b. "Isotopes on the beach Part 2 Neodymium isotopic analysis for provenancing Roman glassmaking." Archaeometry 55, 449-464. 
Brems, D., Degryse, P., 2014. "Trace element analysis in provenancing Roman glassmaking." Archaeometry 56, Suppl. 1, 116-136.

Brems, D., Pauwels, J., Blomme, A., Scott, R., Degryse, P., 2016. Geochemical heterogeneity of sand deposits and its implications for the provenance determination of Roman glass. STAR: Science and Technology of Archaeological Research 1:2, 115-124.

Brill, R.H., 1967. A great glass slab from ancient Galilee. Archaeology 20, 88-95.

Brill, R.H., 1988. Scientific investigations of the Jalame glass and related finds. In: Weinberg, G.D. (Ed.) Excavations at Jalame. Site of glass factory in Late Roman Palestine. Missouri Press, Columbia, 257-294.

Brill, R.H., 2012. Reference glasses A, B, C, and D: Trace and ultra-trace elements. In: Brill, R.H., Stapleton, C.P. (Eds.) Chemical analyses of early glasses, Volume 3: The Years 20002011, Reports, and Essays. Corning Museum of glass, Corning, New York. 567-574.

Degryse, P., 2014. Glass Making in the Greco-Roman World: Results of the ARCHGLASS project. Leuven University Press, Leuven.

Degryse, P., Schneider, J., 2008. Pliny the Elder and Sr-Nd isotopes: tracing the provenance of raw materials for Roman glass production. Journal of Archaeological Science 35, 1993 2000 .

Degryse, P., Shortland, A., 2009. Trace elements in provenancing raw materials for Roman glass production. Geologica Belgica 12, 135-143.Degryse, P., Schneider, J., Lauwers, V., De Muynck, D., Vanhaecke, F., Waelkens, M., Muchez, Ph., 2006. Sr and Nd isotopic evidence in the primary provenance determination of Roman glass from Sagalassos (SW Turkey). Annales du 17e Congrès de l'Association Internationale pour l'Histoire du Verre, Anvers, 564-570.

Degryse, P., Schneider, J., Lauwers, V., De Muynck, D., Vanhaecke, F., Waelkens, M., Muchez, Ph., 2006. Sr and Nd isotopic evidence in the primary provenance determination of Roman glass from Sagalassos (SW Turkey). Annales du 17e Congrès de 1'Association Internationale pour l'Histoire du Verre, Anvers, 564-570.

Degryse, P., Schneider, J., Lauwers, V., Brems, D., 2008. Sr-Nd isotopic analysis of glass from Sagalassos (SW Turkey). Journal of Cultural Heritage 9, e47-e49.

Degryse, P., Henderson, J., Hodgins, G., 2009a. Isotopes in Vitreous Materials. Studies in Archaeological Sciences. Leuven University Press, Leuven.

Degryse, P., Schneider, J., Lauwers, V., Henderson, J., Van Daele, B., Martens, M., Huisman, H.D.J., De Muynck, D., Muchez, Ph., 2009b. Neodymium and strontium isotopes in the provenance determination of primary natron glass production. In: Degryse, P., Henderson, J., Hodgins, G. (Eds.) Isotopes in Vitreous Materials. Studies in Archaeological Sciences. Leuven University Press, 53-72.

De Muynck, D., Huelga-Suarez, G., Van Heghe, L., Degryse, P., Vanhaecke, F., 2009. Systematic evaluation of a strontium-specific extraction chromatographic resin for obtaining 
a purified $\mathrm{Sr}$ fraction with quantitative recovery from complex and Ca-rich matrices. Journal of Analytical Atomic Spectrometry 24, 1498-1510.

Devulder, V., Degryse, P., 2014. The sources of Natron. In: Degryse, P. (Ed.) Glass Making in the Greco-Roman World: Results of the ARCHGLASS project. Leuven University Press, Leuven, 87-95.

Devulder, V., Degryse, P., Vanhaecke, F., 2013. Development of a novel method for unraveling the origin of natron flux used in Roman glass production based on B isotopic analysis via Multicollector Inductively Coupled Plasma Mass Spectrometry. Analytical Chemistry 85, 12077-12084.

Devulder, V., Vanhaecke, F., Shortland, A., Mattingly, D., Jackson, C., Degryse, P., 2014. Boron isotopic composition as a provenance indicator for the flux raw material in Roman natron glass. Journal of Archaeological Science 46, 107-113.

Foy, D., Nenna, M.-D., 2001. Tout feu tout sable. Mille ans de verre antique dans le Midi de la France. Édisud, Marseille.

Foy, D., Vichy, M., Picon, M., 2000. Lingots de verre en Méditerranée occidentale. Annales du 14e Congrès de l'Association Internationale pour l'Histoire du Verre, Amsterdam, 51-57.

Foy, D., Picon, M., Vichy, M., Thirion-Merle, V., 2003. Caractérisation des verres de la fin de l'Antiquité en Méditerranée occidentale: l'émergence de nouveaux courants commerciaux. In: Foy, D. M-D. Nenna (Eds.) Échanges et Commerce du Verre dans le Monde Antique. Montagnac, Éditions Monique Mergoil. 41-85.

Freestone, I.C., 2006. Glass production in Late Antiquity and the Early Islamic period: a geochemical perspective. In: Maggetti, M., Messiga, B. (Eds.) Geomaterials in Cultural Heritage. Geological Society of London, Special Publications 257, 201-216.

Freestone, I.C., Gorin-Rosen, Y., 1999. The great glass slab at Bet She'Arim, Israel: an early Islamic glassmaking experiment? Journal of Glass Studies 41, 105-116.

Freestone, I.C., Gorin-Rosen, Y., Hughes, M.J., 2000. Primary glass from Israel and the production of glass in the late antiquity and the early Islamic period. In: Nenna, M.D. (Ed.) La route du verre. Ateliers primaires et secondaires de verriers du second millénaire avant J.C. au Moyen Age. Travaux de la Maison de l'Orient Méditerranéen 33, Lyon, 65-83.

Freestone, I.C., Greenwood, R., Gorin-Rosen, Y., 2002a. Byzantine and early Islamic glassmaking in the Eastern Mediterranean: production and distribution of primary glass. In: Kordas, G. (Ed.) Proceedings of the first international conference on Hyalos-Vitrum-Glass. History, technology and conservation of glass and vitreous materials in the Hellenic World, 1-4 April 2001, Rhodes, Greece. Glasnet Publications, Athens, 167-174.

Freestone, I.C., Ponting, M., Hughes, J., 2002b. The origins of Byzantine glass from Maroni Petrera, Cyprus. Archaeometry 44, 257-272. 
Freestone, I.C., Leslie, K.A., Thirlwall, M., Gorin-Rosen, Y., 2003. Strontium isotopes in the investigation of early glass production: Byzantine and early Islamic glass from the Near East. Archaeometry 45, 19-32.

Freestone, I.C., Jackson-Tal, R.E., Tal, O., 2008. Raw glass and the production of glass vessels at Late Byzantine Apollonia-Arsuf, Israel. Journal of Glass Studies 50, 67-80.

Freestone, I.C., Wolf, S., Thirlwall, M., 2009. Isotopic composition of glass from the Levant and the south-eastern Mediterranean Region. In: Degryse, P., Henderson, J., Hodgins, G. (Eds.) Isotopes in Vitreous Materials. Studies in Archaeological Sciences. Leuven University Press, 31-52.

Freestone, I.C., Degryse, P., Lankton, J., Gratuze, B., Schneider, J., 2018. HIMT, glass composition and commodity branding in the primary glass industry. In: Rosenow, D., Phelps, M., Meek, A., Freestone, I.C. (Eds.) Things That Travelled: Glass in the First Millennium CE. London: UCL Press

Ganio, M., Latruwe, K., Brems, D., Muchez, P., Vanhaecke, F., Degryse, P., 2012a. The Sr$\mathrm{Nd}$ isolation procedure for subsequent isotopic analysis using multi-collector ICP - mass spectrometry in the context of provenance studies on archaeological glass. Journal of Analytical Atomic Spectrometry 27, 1335-1341.

Ganio, M., Boyen, S., Fenn, T., Scott, R., Vanhoutte, S., Gimeno, D., Degryse, P., 2012b. Roman glass across the Empire: an elemental and isotopic characterization. Journal of Analytical Atomic Spectrometry 27, 743-753.

Ganio, M., Boyen, S., Brems, D., Scott, R., Foy, D., Latruwe, K., Molin, G., Silvestri, A., Vanhaecke, F., Degryse, P., 2012c. Trade routes across the Mediterranean: a Sr/Nd isotopic investigation on Roman colourless glass. Glass Technology: European Journal of Glass Science and Technology A 53, 217-224.

Gorin-Rosen, Y., 1995. Hadera, Bet Eli'ezer. Excavations and Surveys in Israel 13, 42-43.

Gorin-Rosen, Y., 2000. The ancient glass industry in Israel: summary of finds and new discoveries. In: Nenna, M.D. (Ed.) La route du verre. Ateliers primaires et secondaires du second millénaire avant J.C. au Moyen Age. Travaux de la Maison de l'Orient Méditerranéen 33, Lyon, 49-64.

Gratuze, B., Barrandon, J.-N., 1990. Islamic glass weights and stamps: analysis using nuclear techniques. Archaeometry 32, 155-162.

Henderson, J., 2013. Ancient glass: An interdisciplinary exploration. Cambridge University Press, pp. 423.

Kouwatli, I., Curvers, H.H., Stuart, B., Sablerolles, Y., Henderson, J., Reynolds, P., 2008. A pottery and glass production site in Beirut (BEY 015), Bulletin d'Archéologie et d'Architecture Libanaises 10, 103-130.

Nenna, M.D., 2015. Primary glass workshops in Graeco-Roman Egypt: preliminary report on the excavations of the site of Beni Salama, Wadi Natrun (2003, 2005-9). In: Bailey, J., 
Freestone, I., Jackson, C.M. (Eds.) Glass in the Roman Empire. Oxbow books, Oxford, 122.

Nenna, M.D., Vichy, M., Picon, M., 1997. L'Atelier de verrier de Lyon, du Ier siècle après J.C., et l'origine des verres 'Romains'. Revue d'Archéométrie 21, 81-87.

Nenna, M.D., Picon, M., Vichy, M., 2000. Ateliers primaires et secondaires en Egypte à l'époque Gréco-Romaine. In: Nenna, M.D. (Ed.) La route du verre. Ateliers primaires et secondaires du second millénaire avant J.C. au Moyen Age. Travaux de la Maison de l’Orient Méditerranéen 33, Lyon, 97-112.

Nenna, M.D., Picon, M., Thirion-Merle, V., Vichy, M., 2005. Ateliers primaires du Wadi Natrun: nouvelles découvertes. Annales du 16e Congrès de l'Association Internationale pour l'Histoire du Verre, London, 59-63.

Nicholson, P.T., Jackson, C.M., Trott, K.M., 1997. The Ulu Burun glass ingots, cylindrical vessels and Egyptian glass. Journal of Egyptian Archaeology 83, 143-153.

Phelps, M., Freestone, I.C., Gorin-Rosen, Y., Gratuze, B., 2016. Natron glass production and supply in the late antique and early medieval Near East: The effect of the Byzantine-Islamic transition. Journal of Archaeological Science 75, 57-71.

Picon, M., Vichy, M., 2003. D'Orient en Occident: l'origine du verre à l'époque romaine et durant le haut Moyen Âge. In: Foy, D., Nenna, M.D. (Eds.) Echanges et commerce du verre dans le monde antique. Monographies Instumentum 24. Éditions Monique Mergoil, Montagnac, 17-31.

Shortland, A.J., Schachner, L., Freestone, I.C., Tite, M., 2006. Natron as a flux in the early vitreous materials industry: sources, beginnings and reasons for decline. Journal of Archaeological Science 33, 521-530.

Shortland, A.J., Rogers, N., Erimin, K., 2007. Trace element discriminants between Egyptian and Mesopotamian late Bronze Age glasses. Journal of Archaeological Science 34, 781-789.

Shortland, A., Degryse, P., Walton, M., Geer, M., Lauwers, V., Salou, L., 2011. The evaporitic deposits of Lake Fazda (Wadi Natrun, Egypt) and their use in Roman glass production. Archaeometry 53, 916-929.

Stille, P., Shields, G., 1997. Radiogenic Isotope Geochemistry of Sedimentary and Aquatic Systems. Lecture Notes in Earth Sciences 68, Springer, Berlin, pp. 217.

Sun, S.-s., McDonough, W.F., 1989. Chemical and isotopic systematics of oceanic basalts: implications for mantle composition and processes. Geological Society, London, Special Publications 42, 313-345.

Tal, O., Jackson-Tal, R.E., Freestone, I.C., 2004. New evidence of the production of raw glass at Late Byzantine Apollonia-Arsuf, Israel. Journal of Glass Studies 46, 51-66.

Tal, O., Jackson-Tal, R.E., Freestone, I.C., 2008. Glass from a late Byzantine secondary workshop at Ramla (south), Israel. Journal of Glass Studies 50, 81-95. 
Tanimoto, S., Rehren, T., 2008. Interactions between silicate and salt melts in LBA glassmaking. Journal of Archaeological Science 35, 2566-2573.

Van Beeumen, R., 2011. Numerical modelling of primary glass furnaces in the 1st millennium AD. Unpublished Master Thesis, K.U.Leuven, pp. 44.

Van Beeumen, R., Degryse, P., Eisenga, M., Muijsenberg, E., 2011. Numerical modelling of ancient primary glass furnaces. In: A Collection of Papers, Proceedings of the 11th International Seminar on Furnace Design Operation \& Process Simulation, 21-23 June 2011, Velké Karlovice, Czech Republic. 141-149.

Wagner, B., Nowak, A., Bulska, E., Hametner, K., Günther, D., 2012. Critical assessment of the elemental composition of Corning archeological reference glasses by LA-ICP-MS. Analytical and Bioanalytical Chemistry 402, 1667-1677.

Walton, M.S., Shortland, A., Kirk, S., Degryse, P., 2009. Evidence for the trade of Mesopotamian and Egyptian glass to Mycenaean Greece. Journal of Archaeological Science $36,1496-1503$.

Wedepohl, K.H., 1995. The composition of the continental crust. Geochimica et Cosmochimica Acta 59, 1217-1232.

Wedepohl, K.H., Baumann, A., 2000. The use of marine molluskan shells for Roman glass and local raw glass production in the Eifel area (Western Germany). Naturwissenschaften $87,129-132$.

\section{TABLE CAPTIONS}

Table 1: Comparison of published compositions for the Corning A reference glass (Brill 2012; $\mathrm{P}_{2} \mathrm{O}_{5}$ from Wagner et al., 2012) and the results of 5 measurements of Corning A with LA-ICP-MS, each of which represents an average of three area analyses. Results for $\mathrm{MnO}$, $\mathrm{P}_{2} \mathrm{O}_{5}$ and $\mathrm{TiO}_{2}$ are in $\mathrm{Wt} . \%$. All other results are in ppm. The precision of the analyses is indicated by the standard deviation among the fifteen area analyses and the five individual analyses, while the accuracy can be estimated based on the deviation between the value obtained in this work $\mathrm{C}_{\mathrm{a}}$ and the corresponding reference $\mathrm{C}_{\mathrm{p}}$. This $\delta$ rel $\%$ value is calculated using the formula $\left(\mathrm{C}_{\mathrm{a}}-\mathrm{C}_{\mathrm{p}}\right) / \mathrm{C}_{\mathrm{p}} * 100$.

Table 2: Major, minor and trace element compositions of the glass samples and results of the $\mathrm{Sr}, \mathrm{Nd}$ and $\mathrm{B}$ isotopic analyses. All results for the major and minor oxides are reported in Wt.\%. Trace element concentrations are given in ppm. Each of the trace element measurements represents the average of three area analyses. $\mathrm{SiO}_{2}, \mathrm{Na}_{2} \mathrm{O}, \mathrm{CaO}, \mathrm{Al}_{2} \mathrm{O}_{3}, \mathrm{Fe}_{2} \mathrm{O}_{3}$, $\mathrm{MgO}, \mathrm{K}_{2} \mathrm{O}, \mathrm{Cl}$ and $\mathrm{SO}_{3}$ data are from Bimson and Freestone (1985), Freestone et al. (2000) and $\mathrm{Tal}$ et al. (2004). (nd. = not determined) 